\title{
Towards inconspicuous consumption? Luxury and its pedlars in the current world climate
}

\author{
Luxury World: The Past, Present and Future of Luxury Brands \\ Mark Tungate \\ Kogan Page, London, UK, 2009, 260pp., US\$21.86, ISBN: 978-0749452636 \\ The Luxury Strategy: Break the Rules of Marketing to Build Luxury Brands \\ Jean-Noël Kapferer and Vincent Bastien \\ Kogan Page, London, UK, 2009, 384pp., US\$32.97, ISBN: 978-0749454777
}

Journal of Revenue and Pricing Management (2011) 10, 99-102. doi:10.1057/rpm.2010.37

'Rich enough to afford mink; chic enough to wear it on the inside', said the suave actor of the attractive woman dressed in a red, minklined coat. This was a scene from a 1950s movie I had watched about 20 years ago. Whereas the movie's title and actors' names have eluded my memory, that statement had stuck with me for some reason. In recent decades, attitudes to wearing animal fur have been changing, but the note on private indulgence in quality and luxuriance is a key theme in Luxury World. Styled along the lines of travel literature, Tungate takes his readers round the world in 20 chapters. Engagingly written with many anecdotes and well-told tales, each chapter is relatively short and has a snazzy title like 'Rolling the stones' or 'Watch the watchmakers'. In this trip, the search is for the varieties in meanings of luxury and the ways in which luxury's pedlars enact their part. I found the central theme to be: luxury; whence and whither?

In discovering 'whence', the reader is tagged along for visits to various brand houses and their regions. The usual temptations are conjured up: diamonds, fine wine, cars and yachts. At times, however, there are too many points of interest in this world tour, several of which could use more elaboration. Turning to 'whither', it seems that luxury is travelling routes with the same labels as the rest of us: 'well-being', 'digital', 'knowledge economy' and 'sustainability' - but as usual it is going first class. Well, at least for the largest part; 'digital', apparently, is a more tenuous path for luxury's pedlars, so I will come back to it later. Also, I am usually wary of the increasing commodification of education in a globalizing 'knowledge economy', but I am old enough to know it has been happening for a long while.

So what about luxury today? There is something charismatic in the book's message: now is the time for savoir-faire over bling, the time to 'decouple' luxury from fashion and brace it with quality. Or rather, 'excess is out of fashion', and so the industry is falling back on craftsmanship. This sense of urgency could be driven by the author's immersion as a journalist in media coverage of consumer sentiments. In 2008, The Economist had commented on a 34 per cent decline in luxury-goods spending and noted that there was a feeling that it was wrong to show off at a time of recession in which people felt poor (not to mention 'flash 
fatigue'). A year later, contra Silverstein and Fiske's arguments in Trading up: The new American Luxury, it argued that people were 'trading down' and surveyed newly coined phrases like 'austerity chic' and 'luxury shame'. Altogether, however, this is not a new phenomena; wariness of ostentation has made the rounds for centuries, if not millennia.

What Tungate's world tour lacked is a variegated and nuanced coverage of the enticing variety in cultural and ethnic traditions of luxury around the world and how these are being isomorphed through the effects of globalization - or rather westernization. I have to admit that my anticipation for such an assay was set when the book started with the petite client from the Gulf States, but it was not forthcoming. Ultimately, the book is written from the west's point of view, mostly about its European traditions, and presents a luxury world far less diverse than the one we live in. Where the book is genuinely, if briefly, reflective is on the possibility of contemporary redefinition of luxury. For example, there is the argument that true luxury is either priceless or free. There is also the appreciation of slow living as luxury in a time-starved world, and analogue snobbery: when users shun the modern item in favour of its older antecedent - like savouring vinyl records or film cameras over their digital substitutes. It looks like Tungate sees this last trend as shaping his future, describing how newspapers 'will portray their journalists as wordsmiths - craftsmen' and that even today, 'A hardback book is a luxury item'.

You do not need to be in business to appreciate this book - simply with the curiosity in how the luxury world works. There are no flashes of revelation here, but then these were never promised. The book sets out to deliver a 'portrait' - that is to be informative and interesting - and achieves this. The index could be more thorough. I went looking for 'butler', that classic icon of luxuriant service, but could not find it. (Yes, it was covered in the book.) Altogether, Tungate's experience in journalism ensures that the writing is accessible to many, and his account of luxury leaves the reader with something to talk about at their next teaching session or dinner party whichever comes first. The book's last word? 'Consumers come and go, economies boom and bust - but luxury endures'.

Apparently, it has done so for a while. 'In the beginning, there was luxury', write Kapferer and Bastien in The Luxury Strategy. Luxury's origins demonstrate its lineage: the ancients (Egyptian, Greek or Chinese) luxuriated when they could afford it. It should then follow that luxury's pedlars must also have held one of the world's oldest professions. The focus of the book is on the strategic implications for organizations that set out on the luxury path. Its subtitle is Break the rules of marketing to build luxury brands. For the largest part, the marketing rules being broken here are the generic ones (such as those around positioning, price and so on). The book reinforces the rules of the game already established by luxury brands. There are 12 commandments - or rather 'antilaws of marketing' - that include admonitions like 'don't respond to rising demand' and 'make it difficult for clients to buy'. Luxury, we are taught, is neither 'premier' nor 'fashion'. Flaunting it is not the issue here; rather, 'luxury for others' is positioned as a defining factor alongside 'luxury for oneself'. The premise is that to have lasting success a product or service must embody luxury as a social statement alongside luxury as an individual pleasure. These two principles are operationalized through two respective indices by the Luxury Institute in the USA: the Luxury Brand Status Index and the Luxury Customer Experience Index.

The book is full of tips, often dispensed with authority and confidence. (At times support for the claim are intuitive and yet to be offered.) The style is reflective of the role of industry experience held by the authors: trust us; we know what we are writing about. Altogether, it is a veritable mine of diagrams, matrices and pyramids on topics such as brand distinction, identity, architecture, communication and 
business modelling. It is well illustrated with organizational and branding examples. It would make for a good teaching text since students are likely to appreciate the aura of certainty that it projects. I wish I could share the sentiment in some parts. 'No sales in luxury'? The argument is that sales are anathema to luxury's leisurely purchase, wherein emphasis is always on product over price. Sure the Sale signs do not go up in luxury shops, but the prices do go down. The authors acknowledge price reductions as an opportunity in certain cases to certain clients. However, the recession in 2009 has meant that shoppers can be more brazen in offering a price and haggling to an agreement. Further, the elite are discrete at taking care of distasteful business: sales are out of sight - in the virtual world, not on the shop floor. In 2009, The Economist reported that luxury e-tailers boasted a booming business in clearing previous seasons' wares on behalf of designers for as low as 20 per cent of the original price. They do so quickly and with an aura of exclusivity that luxury brands cherish (site members are 'by invitation').

This brings me back to luxury's ambivalence about going digital, as if there were something déclassé about it. Kapferer and Bastien state that luxury should not be sold through TV and in a similar vein declare that 'a luxury product can communicate via the Internet, but should not be sold there'. This sounds so last decade. An identical statement was made by Businessweek in 2000: 'selling luxury items ... online is not going to work ... This is not to say luxury companies don't belong online - the do. Just not as retailers'. The arguments against luxury digital retail are that it dilutes the client relationship and makes the price more explicit. Tungate notes that the industry's concern, 'what to do about the internet', was overshadowed by the economic crisis in 2008. Yet, even till 2006, the World Luxury Congress hardly mentioned the benefits to going online. Meanwhile, upmarket consumers were getting younger and were at ease with the digital environment. Further, selling through the
Internet is more than having a website and retail outlet; it is also about working with bloggers and through social networks. Tungate concludes his brief exposé by noting that even though at the back of the crowd, 'luxury brands have finally joined the digital revolution'. This seems to have generated enough material for Luxury Online by Uche Okonkwo. Like Tungate, the author points to the role of the vacuum generated by the industry lag in enabling counterfeiters to occupy virtual space. While paying closing attention to avoiding channel conflict, luxury firms are adding new tricks to their trade by going digital. But all is not smooth sailing. There is still the learning curve. As The Economist stated in 2010: 'It is odd that an industry that would not be seen dead in last season's colour is wedded to the last century's technology'. Altogether, it appears that it is difficult to be overly prophetic of the impact to be generated should the luxury world align with the digital world. Currently, the luxury pedlars are dipping their toes into the digital waters and testing them. Only time and generations will tell if the ephemeral character of cyberspace eludes or engulfs them.

To me, the value of The Luxury Strategy lay in some of the enticing snippets that left me wanting more. Here and there, it acknowledged the relativity and cultural specificity of luxury. I wished this were more systematic and in-depth. The short section on the role of national identity is worth developing. What happens if/when these crown jewels are to be acquired by foreign firms? There is mention of the role of desire, but too little and too late in the piece. The deferral of gratification, the wait, which is a necessary supplement to desire, is also intriguing. These twin notions deserve more explication. (Neither 'desire' nor 'time' appear in the index.)

I like where the book ends up, but it leaves me somewhat confused. It closes with sections on 'ethics' (which it also invoked at the outset) and 'sustainability'. Under ethics, it pronounces that luxury 'is not ostentation'. Come again. What happened to the earlier sections on 
'luxury for others' and the Luxury Brand Status Index? The section on sustainability notes some insightful ways by which luxuries potentially address both 'ecological satisfaction and social restratification'. It also affirms that a luxury product is endowed with a long lifespan. Umm. The acid test: where have all the leftover products gone? This is a test of principles. Some luxury firms are known to destroy previous seasons' stocks rather than sell them at a discount. As the authors had stated in an earlier example: 'this apparently anti-economical action is in fact the consequence of the strict application of a luxury strategy in leather goods, and the benefits ... make up for the cost of the destruction of a few fancy handbags'. (Incidentally, the destruction of wealth to assert status was also practiced in ancient Greece.) Reusing (or even using) is dear to sustainability. So while an unsold product is systematically shredded to preserve brand value, it will be a bit rich for that product to claim 'sustainability'. Ultimately, the message I chose to take away from this book is this: in an age of superfluous consumption, luxury can make its stand by delimiting value. We are all aware that the finite is often more precious than the infinite. We know the cliché: less can be more. But it is easy to forget this as we are compelled to produce and urged to consume.

I have used 'pedlars' in this title in deliberate resistance to the common misconception that luxury firms constitute a different species; they simply command a different persona. Both books confirmed this for me. Firms trading in luxury products and services have to sell just like any other. They just have to go about it differently. Subtly. (Or as classical marketing would have stated: by pulling not pushing.) They charm clients with a soft tone and suggestive flair. Their style can be enamouring and flirtatious for some, but distant and aloof to many. They generate dreams of havens ('for oneself' and 'for others') and instil the aspiration in some people to join them. Ultimately, their wares have to be approached as objects of desire, even if based on quality, and even if they have to be more discretely savoured. The last may well enhance the pleasure.

\section{REFERENCES}

Businessweek. (2000) Online luxury has its limits. 18 September. Economist. 'Bling on a budget' (4 April 2009); 'Trading down; from decadence to discounts' (30 May 2009); 'When cheap is exclusive; selling designer goods online' (5 September 2009); 'The chic learn to click' (24 July 2010).

Okonkwo, U. (2010) Luxury Online: Style, Systems, Strategies. Hampshire, UK: Palgrave Macmillan.

Silverstein, M.J. and Fiske, N. (2005) Trading Up: Why Consumers Want New Luxury Goods - And How Companies Create Them. New York: Portfolio.

Sally Riad

Victoria University of Wellington, Wellington, New Zealand 